\title{
Hybrid Electric Charging Station using Raspberry $\mathrm{Pi}$
}

\author{
Arabi Madharshan, Aravinth, Dheneshraajan, Gokul, P. Praveena
}

\begin{abstract}
Our world is running out of fossil fuel so people start to change themselves and started to use an electric vehicle. In electric vehicles the charging is a big deal, this project includes solar and wind energy charging mechanism to generate power for electric vehicle both day and night. And it contains Raspberry pi that is programmed to calculate the amount of power charged for an electric vehicle, then the user can know that the information via Blynk application. The power generated by solar panel setup is given to the battery via $D C-D C$ converter because the power from solar panel setup is a variable $D C$, so that is converted into pure $D C$. And the power generated by wind generator setup is given to battery via $A C-D C$ converter, the power from a wind generator is $A C$, so that is converted into $D C$.
\end{abstract}

Keywords: Battery, Charge Controller, Raspberry Pi, Solar Panel.

\section{INTRODUCTION}

$\mathrm{E}_{\text {arth is running out of fossil fuels, so people are hurrying }}$ to seek out alternative sources of energy and ways to provide them. Using electric vehicles might be the answer to scale back employment of fossil fuel, and also mitigate a separate issue the quantity of $\mathrm{CO} 2$ emissions. Electric cars are so useful, but not everyone seems to be driving them yet. Due to two reasons, price and charging. Electric vehicles (EV) are too expensive for the mass market, and finding a charging station is just too difficult. Thee worth of the vehicle cannot be reduced, but the charging of the vehicle will be made easy by building an EV charging point reception. Thee worth is one of the most important factors for many people preventing the utilization of electrical cars. the worth of an electrical car largely depends on the battery. Big "fuel tanks" cost lots, but bigger the battery, the longer the EV can persist one charge. They require no staff or cashiers, and that they take up little

Revised Manuscript Received on September 15, 2020.

* Correspondence Author

Arabi Madharshan*, Under Graduate Student, Electrical and Electronics Engineering, KPRIET, Arasur, Kovai (Tamil Nadu), India

Aravinth, UG Scholar, Under Graduate Student, Electrical and Electronics Engineering, KPRIET, Arasur, Kovai (Tamil Nadu), India

Dheneshraajan, Under Graduate Student, Electrical and Electronics Engineering, KPRIET, Arasur, Kovai (Tamil Nadu), India

Gokul, Under Graduate Student, Electrical and Electronics Engineering, KPRIET, Arasur, Kovai (Tamil Nadu), India KPRIET, Arasur, Kovai (Tamil Nadu), India

(c) The Authors. Published by Blue Eyes Intelligence Engineering and Sciences Publication (BEIESP). This is an open access article under the CC BY-NC-ND license (http://creativecommons.org/licenses/by-nc-nd/4.0/)
Praveena P, Assist Prof, Electrical and Electronics Engineering,

space. So, battery-powered vehicles have a bright future than fuel vehicles.

\section{PROPOSED METHODOLOGY}

The power generated by the solar panel setup feds to the battery via the DC-DC converter and charge controller. The current from the solar panel is taken by the DC-DC converter and passes it through the switching element and this turns the DC signal to AC signal. Then that converted AC wave passes through another filter which converts AC to signal of required voltage level. And also the power generated by the wind generator feds to the battery via AC - DC converter and charge controller. The Power from the wind generator is the AC signal, but the battery needs DC signal only so that only AC - DC converter is employed here. The charge controller is to regulate the current in batteries during charging. The battery is connected to Raspberry pi, which is programmed to calculate the amount of power have charged to electric vehicles and that information will send to the user via Blynk application.

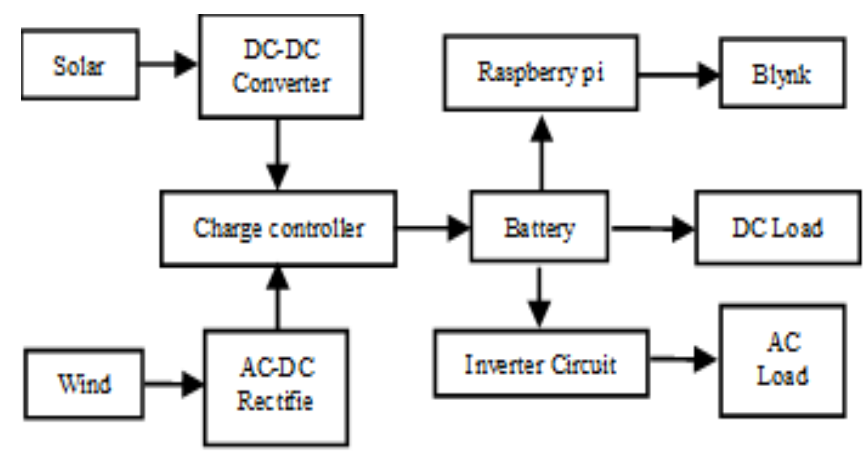

Fig. 1. Block Diagram

\section{A. Raspberry Pi 3}

It is a small development board minicomputer and that runs in a Linux based system, and it was by Raspberry $\mathrm{Pi}$ Foundation. It has USB sockets, which support numerous peripheral plug-and-play gadgets just like the keyboard, the mouse, the printer, etc. It has a video port HDMI (High Definition Multimedia Interface) to offer customers with video output. It consists of an ARM1176JZF-S 700 Meha Herts processor, 512 MegaBytes of Random Access Memory, and Video Core IV Graphics Processing Unit. And the speed of the board is $0.7 \mathrm{GHz}-1.4 \mathrm{GHz}$. It has an On-board memory of $1 \mathrm{~GB}$ random-access memory (RAM). The board has 1 to 4 USB ports. And it contains an 8P8C Ethernet port.

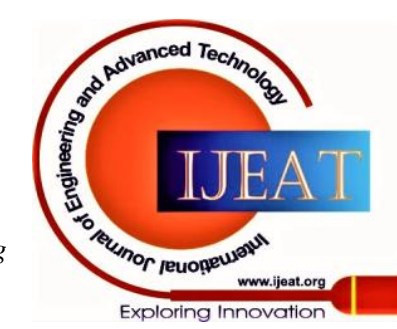




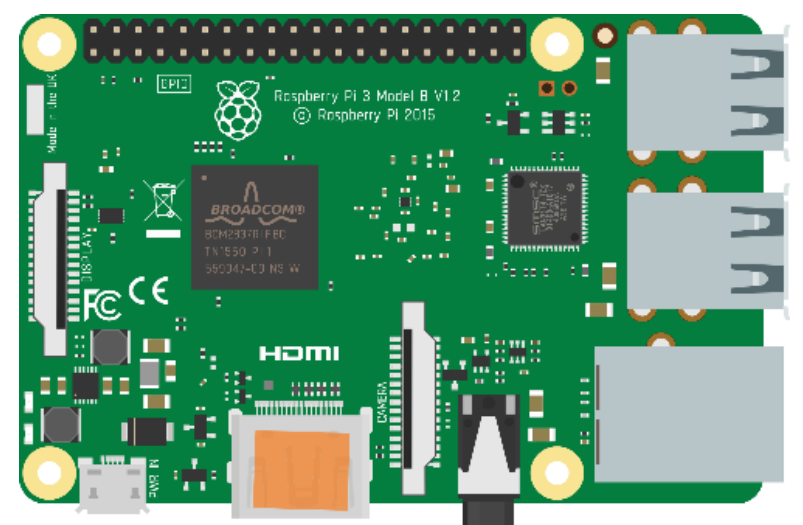

Fig. 2. Raspberry Pi 3

\section{B. Solar Panel}

The solar panel is an electrical device that absorbs sunlight and converts it into electricity. It is made up of solar cells or photovoltaic cells which is used to generate electricity by the photovoltaic effect. These cells are arranged on the surface of the solar panel in a pattern of a grid system. It is also called a photovoltaic module. Crystalline of silicon is used to make these cells. And these solar panels are collectively called a solar array. Electric current is initiated by the absorption of photons in the solar panel. Which interns strikes the photons in the solar panel to generate directional current.

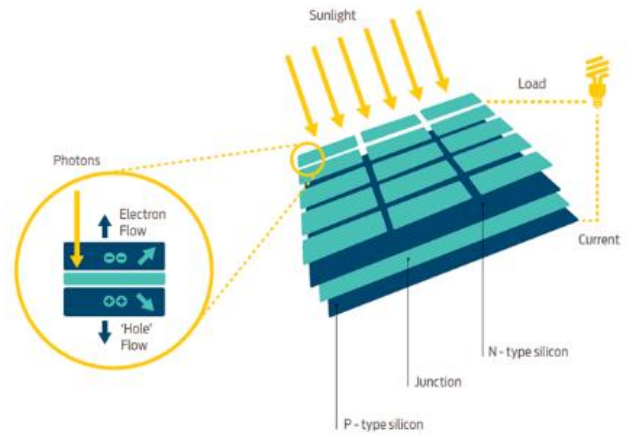

Fig. 3. Solar Panel

This process is called the Photovoltaic effect. This direct current passes through the charge controller which is used to maintain the standard value. And it is passed the battery for the storage of the electricity. Then the electricity in the battery can be used by the direct current devices. For alternating current devices, the electricity must be converted to alternating current, it is done by using an inverter.

\section{12V Battery}

A battery is a storage device. Which stores chemical energy and converts the chemical energy into electrical energy. This is called electrochemistry and the system that supports the battery is called electrochemical cell. A battery can be made up of several electrical cells. And each electrochemical cell contains two electrodes. These electrodes are separated by a layer of electrolyte. The electrons are produced by reactions of chemicals in the battery. And the electrons start to flow from one electrode to another. And it is named as anode and cathode. The flow of electrons causes electricity. And these electrodes are placed in an electrolyte. Different standards are used to palace the electrodes. Which to create greater electrochemical potential.

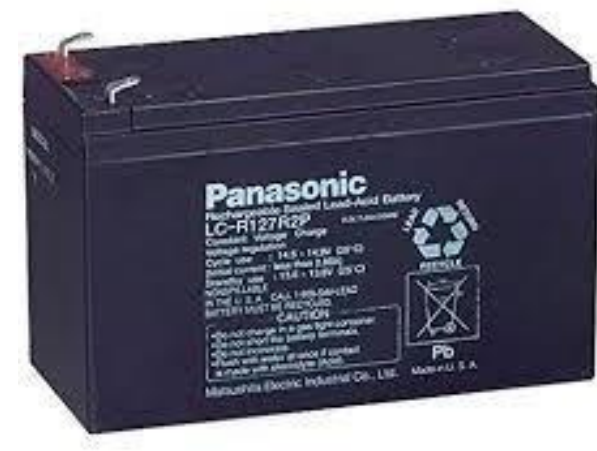

Fig. 4. 12V Battery

\section{Rectifier}

Current flowing through a circuit may be AC or DC. A car battery or any other type of battery use DC volts. A $12 \mathrm{~V}$ battery is installed for use. The predominant method of portable electronics is $12 \mathrm{~V}$ sack which is used in four-wheelers, buses, motorcycles, hovercrafts are powered.

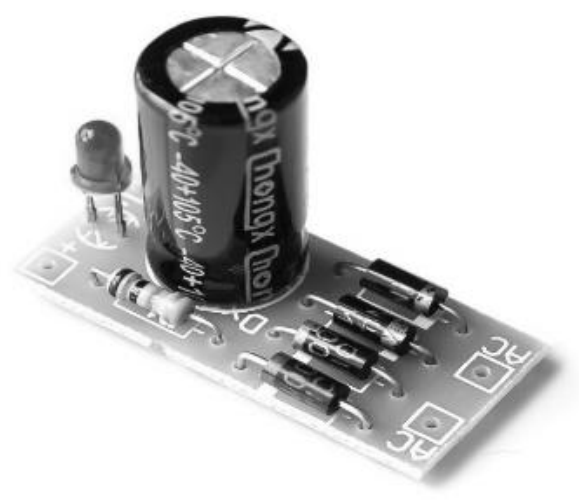

Fig. 5. Rectifier

Na typical $781212 \mathrm{~V}$ regulators, it needs at least $14 \mathrm{~V}$ to work properly. If it's a lower voltage regulator $(9 \mathrm{~V}$ or $5 \mathrm{~V})$ it might work fine. With alternating current, current flows through 4 diodes, DC only uses 2. So they have to handle double the current which may or may not be fixed.

\section{E. DIRECT CURRENT - DIRECT CURRENT CONVERTER}

The name indicates the Direct Current - Direct Current converter converts a value of one voltage level to another. This is necessary to provide accurate voltage to sensitive circuits like Integrated Circuits. A Direct Current - Direct Current converter is also called a linear or switching regulator. In Direct current supply, the charge carries flows in a straight direction. Direct current voltage produces a constant amount of electricity. The Direct Current - Direct Current converter is used to increase or decrease the voltage level. It is necessary to provide a certain value of the voltage to some devices. Unless this much of power could destroy the device.

Published By:

Blue Eyes Intelligence Engineering and Sciences Publication (C) Convriaht: All riahts reserved 


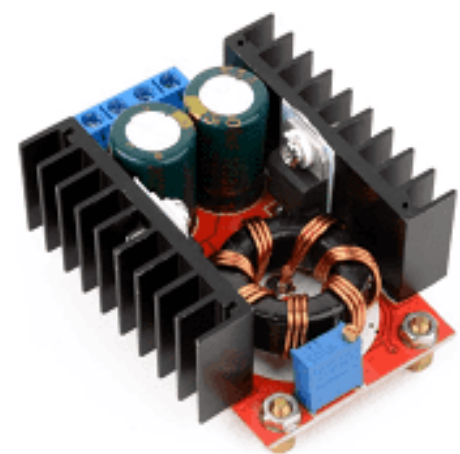

Fig. 6. Direct Current - Direct Current Converter

\section{RESULT}

The following result was taken from the Blyk application. The power generated by the hybrid mechanism is consumed by the load and the amount of consumed power is obtained in the Blynk application.

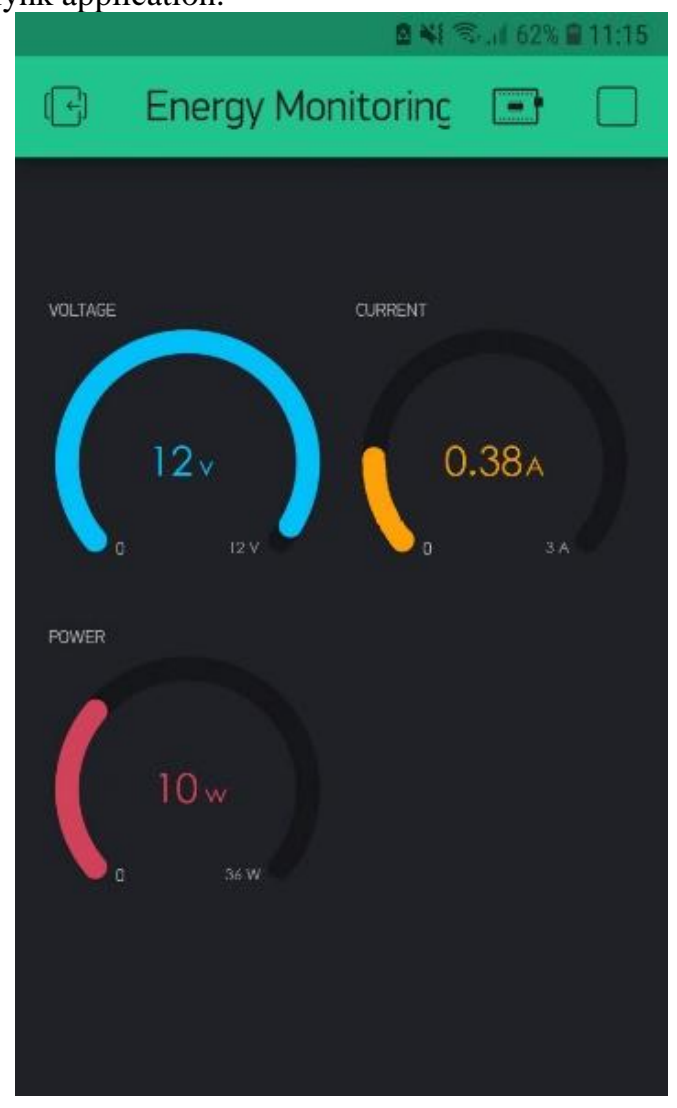

Fig. 7. Output Result

\section{CONCLUSION}

In this paper, we present the idea of the charging mechanism for an electric vehicle by using solar and wind energy. For longer drive vehicle one-time charging would not be enough so charging station is a mandatory one. In this hybrid charging station, electric vehicles can be charged at both day and night time. And the user can know the amount of power consumed to charge the vehicle. By this system, the emission of greenhouse gases and the increase in the usage of the electric vehicle can reduce the pollution level of the environment.

\section{REFERENCES}

1. B. Koushik, A. Safaee, P. Jain, and A. Bakhshai, "A bi-directional single-stage isolated ac-dc converter for EV charging and v2g," in Electrical Power and Energy Conference (EPEC), 2015 IEEE.

2. P. Goli and W. Shireen, "PV Integrated Smart Charging of PHEVs Based on DC-Link Voltage Sensing," IEEE Trans. Smart Grid, vol. 5, no. 3, May 2014.

3. D. P. Birnie, "Solar-to-vehicle (S2V) systems for powering commuters of the future," J. Power Sources, vol. 186, Jan. 2009.

4. M. Yilmaz and P. T. Krein, "Review of Battery Charger Topologies, Charging Power Levels, and Infrastructure for Plug-In Electric and Hybrid Vehicles," IEEE Trans. Power Electron., vol. 28, May 2013.

5. G. R. Chandra Mouli, P. Bauer, and M. Zeman, "System design for a solar-powered electric vehicle charging station for workplaces," Appl. Energy, vol. 168, pp. 434-443, Apr. 2016.

6. O. Hafez and K. Bhattacharya, "Optimal design of electric vehicle charging stations considering various energy resources," Renewable Energy, vol. 107, pp. 576-589, 2017.

\section{AUTHORS PROFILE}

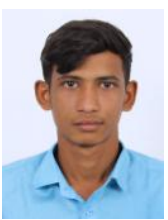

Arabi Madharshan A., Under Graduate Student, Electrical and Electronics Engineering, KPRIET, Arasur, Kovai.

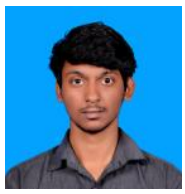

Aravinth R., Under Graduate Student, Electrical and Electronics Engineering, KPRIET, Arasur, Kovai.

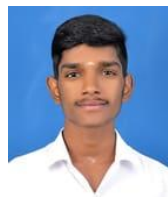

Dheneshraajan K., Under Graduate Student, Electrical and Electronics Engineering KPRIET, Arasur, Kovai.

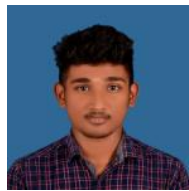

Gokul J., Under Graduate Student, Electrical and Electronics Engineering, KPRIET, Arasur, Kovai.

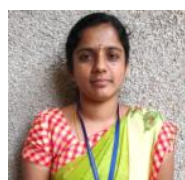

Praveena P., Assist Prof, Electrical and Electronic Engineering, KPRIET, Arasur, Kovai.

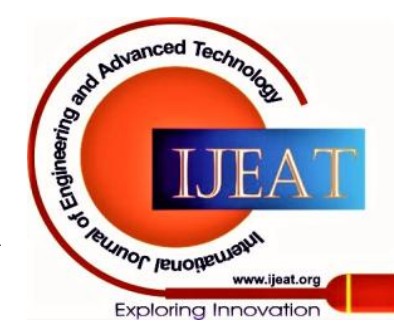

